\title{
Circulation of Knowledge in a Co-innovation Network: An Assessment Approach
}

\author{
Paula Urze ${ }^{1}$ and António Abreu ${ }^{2}$ \\ ${ }^{1}$ FCT/UNL, Faculdade de Ciências e Tecnologia da Universidade Nova de Lisboa, Portugal \\ SOCIUS - Centro de Investigação em Sociologia Económica e das Organizações \\ ${ }^{2}$ ISEL/IPL - Instituto Politécnico de Lisboa, Portugal \\ CTS - Uninova - Instituto de Desenvolvimento de Novas Tecnologias \\ pcu@fct.unl.pt, ajfa@dem.isel.ipl.pt
}

\begin{abstract}
The development of complex products and services require the domain of distinct types of knowledge that enterprises do not usually hold. In order to address this problem, the issue of assessment the knowledge circulation in collaborative environments started to attract attention. Starting with some discussion on mechanisms of production and circulation of knowledge that might operate in a collaborative environment, this paper introduces an approach for assessing knowledge circulation in a co-innovation network. Finally, based on experimental results from a Portuguese collaborative network, BRISA network, a discussion on the benefits, challenges and difficulties found are presented and discussed.
\end{abstract}

Keywords: Circulation of Knowledge, Collaborative Networks, Case Study.

\section{Introduction}

In order to be competitive enterprises must develop capabilities that will enable them to respond quickly to market needs. According to several authors, one of the most relevant sources of competitive advantage is the innovation capacity. [1]. The development of complex products or services requires access to several distinct types of knowledge that enterprises do not usually hold. As a result, in order to solve the lack of knowledge, enterprises can get new knowledge either from their own assets, making sometimes high investments or from the knowledge that may be mobilized through other enterprises based on a collaborative process. Literature in the field has pointed out that the participation in a collaborative process brings benefits to the involved entities [2] [3].

In fact, there is an intuitive assumption that, when an enterprise is a member of a long-term networked structure, the existence of a collaborative environment enables the increase of knowledge circulation as well as the production of knowledge within the network, and thus enterprises may operate more effectively in pursuit of their goals. In other words, the network acts as a channel to transfer knowledge from one organization to another, and may become the locus of new knowledge creation, rather than within the organizations members of the network. 
However, in spite of this assumption, it has been difficult to prove its relevance due to the lack of performance indicators that assess the production and circulation of knowledge in collaborative environment. In this context, the definition and application of a set of indicators can be a useful instrument to the network manager, to a VO broker, and also to network members.

This work aims at contributing to answer the following main questions:

- What are the factors that facilitate co-production of knowledge in collaborative environment?

- How can competences circulation be analyzed in a collaborative context based on an inter-organizational perspective in order to support decisionmaking processes?

\section{Production and Circulation of Knowledge in Collaborative Networks}

In the emergent economy and society, the accumulation of knowledge becomes the main motivational strength towards growth and development. The knowledge-based economies are, essentially, economies where the knowledge managing activity, in relation to the innovating process, has become decisive in the competition among economic actors [4]. Networking, dense social networks, trust, cooperation, learning and knowledge accumulation and circulation are some of the key intangible factors of the knowledge-based economy. It is now commonly accepted that knowledge ranks first in the hierarchy of strategically relevant resources [5].

According to Gibbons et al [6] the exchange of information between scientific institutions and the commercial community is increasing through networking. The new industrial communities are characterized by a trend for knowledge production processes as a new pattern characterizing the new societies. The multidisciplinary nature of knowledge-based production is less isolated and on the other hand the network relations take a new relevance. This networked trend requires a collaborative participation of multiple disciplines and institutions in a bounderless collaboration space where knowledge sharing and value takes a relevant importance. The distributed character of knowledge production constitutes a fundamental change. To it are linked other dimensions of change: the marketability of knowledge, the blurred boundaries between disciplines and institutions and across institutional boundaries, increasing importance of hybrid fora in the shaping of knowledge. Gibbons presents a distinction between Mode 1 knowledge production, which has always existed, and Mode 2 knowledge production, a new mode that is emerging next to it and is becoming more and more relevant. While knowledge production used to be located primarily at scientific institutions (universities, government institutes and industrial research labs) and structured by scientific disciplines, its new locations, practices and principles are much more heterogeneous. Mode 2 knowledge is produced in different organizations, resulting in a very heterogeneous practice. The range of potential sites for knowledge production includes not only the traditional universities, institutes and industrial labs, but research centers, government agencies, think-tanks, high-tech spin-off as well. The Table1 illustrates the two modes (I, II) of knowledge production and its characteristics taking as reference the collaborative networks. 
Table 1. Modes of Knowledge Production

\begin{tabular}{|l|l|l|}
\hline Modes of knowledge production & \multicolumn{1}{|c|}{ Mode 1 } & \multicolumn{1}{|c|}{ Mode 2 } \\
\hline Problem solving & academic community & context of application \\
\hline Nature of Knowledge & Disciplinary & Transdisciplinary \\
\hline Communication of knowledge & $\begin{array}{l}\text { Dissemination trough } \\
\text { established institutional } \\
\text { channels }\end{array}$ & $\begin{array}{l}\text { Diffusion though problem solving } \\
\text { and shared in new contexts of } \\
\text { application }\end{array}$ \\
\hline Organizational form & Hierarchical & Networked \\
\hline
\end{tabular}

Mode 2 refers to a production and transfer of knowledge, which is not exclusively reserved for qualified academic research, but which focuses on the different actors integrated in a contextualised problem solving oriented process. The importance of knowledge is then assessed by its interest to stakeholders engaged in the process of production. This perspective is particularly relevant considering our case study.

\section{Indicators of Production and Circulation of Competences}

Having in mind the knowledge transfer model designed by Urze and Abreu [7] under the CoRe project ${ }^{1}$, which incorporates three main dimensions, it is our purpose in this paper to develop mainly the competences management one, by creating a set of indicators. The absence of indicators related to production and circulation of knowledge clearly showing the amount of new knowledge created and transferred, might be an additional obstacle for a wider acceptance of collaborative-networked paradigm. Taking into account the context of collaborative networks and adopting indicators developed by Abreu and Camarinha-Matos [8] to assess how the assets are shared in collaborative networks, Table 2 shows a number of basic indicators that can contribute to evaluate the level of expertise of an enterprise and how production and circulation of knowledge is done within the network. Furthermore, these indicators can be determined for a particular collaboration process or over a period of time (average values) and can be used in decision-making processes, such as the planning of a new collaborative network.

Table 2. Indicators for competences production and circulation analysis

\begin{tabular}{|c|l|l|}
\hline Indicator & \multicolumn{1}{|c|}{ Short Description } & \multicolumn{1}{|c|}{ Expression } \\
\hline $\begin{array}{c}\text { Total of } \\
\text { Competences }\end{array}$ & $\begin{array}{l}\text { Definition } \\
\text { The number of distinct competences held by the network. } \\
\text { Potential Use } \\
\text { (C) }\end{array}$ & $\begin{array}{l}\text { C }- \text { Number of } \\
\text { distinct competences } \\
\text { involved in indicator measures the level of } \\
\text { versatility/polyvalence of the network. }\end{array}$ \\
\hline
\end{tabular}

1 The present results are based on research work developed under the project - CoRe Competências de I\&D para a Criação de Valor na Rede Brisa, FCT/UNL, BRISA, ISEL/IPL, 2011-2012. 
Table 2. (continued)

\begin{tabular}{|c|c|c|}
\hline $\begin{array}{c}\text { Total of } \\
\text { enterprise } \\
\text { Owned } \\
\text { Competences } \\
\text { (TOC) }\end{array}$ & $\begin{array}{l}\text { Definition } \\
\text { The number of distinct competences held by an enterprise. } \\
\text { Applying concepts from Social Network, it corresponds to } \\
\text { the enterprise's node degree. } \\
\text { Potential Use } \\
\text { This indicator measures the level of expertise and the } \\
\text { potential capacity of an enterprise in terms of knowledge } \\
\text { transfer. }\end{array}$ & $\begin{array}{l}\text { TOC }=\text { Number of } \\
\text { competences held by } \\
\text { an enterprise. }\end{array}$ \\
\hline $\begin{array}{l}\text { Apparent } \\
\text { Owned } \\
\text { Competence } \\
\text { Index } \\
\text { (AOCI) }\end{array}$ & $\begin{array}{l}\text { Definition } \\
\text { The ratio between the number of competences that belong } \\
\text { to an enterprise and the number of distinct competences } \\
\text { held by the network. } \\
\text { Potential Use } \\
\text { An enterprise with an AOCI close to one means that this } \\
\text { enterprise is the owner of nearly all competences available } \\
\text { within the network. }\end{array}$ & $\begin{array}{l}\qquad A O C I=\frac{T O C}{M} \\
\mathrm{M}-\text { Number of } \\
\text { competences held by } \\
\text { the network }\end{array}$ \\
\hline $\begin{array}{c}\text { Owned } \\
\text { Competences } \\
\text { Index } \\
\left(\mathbf{O C I}_{\mathbf{i}}\right)\end{array}$ & $\begin{array}{l}\text { Definition } \\
\text { The ratio between the number of competences that belong } \\
\text { to an enterprise and the sum of the number of distinct } \\
\text { competences held by all enterprises involved in the } \\
\text { network. } \\
\text { Potential Use } \\
\text { - Normalization of the number of competences } \\
\text { held by an enterprise in relation to other members of } \\
\text { the network. } \\
\text { - Benchmarking with enterprises involved in } \\
\text { other networks. }\end{array}$ & $\begin{array}{l}\qquad O C I_{i}=\frac{T O C_{i}}{\sum_{j=1}^{N} T O C_{j}} \\
\mathrm{~N}-\text { Number of } \\
\text { enterprises involved } \\
\text { in the network }\end{array}$ \\
\hline $\begin{array}{c}\text { Owned } \\
\text { Competences } \\
\text { Progress Ratio } \\
\left.(\mathbf{O C P R})_{i}\right)\end{array}$ & $\begin{array}{l}\text { Definition } \\
\text { The ratio of the owned competences index of an } \\
\text { enterprise in two distinct periods of time. } \\
\text { Potential Use } \\
\text { - The aim of this ratio is to measure the progress } \\
\text { of competences held by an enterprise over a period of } \\
\text { time. If: } \\
\left.\qquad O C P R_{i\left[t_{1}, t_{2}\right]}\right\}\left\{\begin{array}{lll}=1 \text { there is no change } \\
>1 & O C P R_{i} \text { increased } \\
<1 & O C P R_{i} \text { decreased }\end{array}\right. \\
\text { other networks }\end{array}$ & $O C P R_{i\left[t_{1}, t_{2}\right]}=\frac{\left(O C I_{i}\right)_{t_{2}}}{\left(O C I_{i}\right)_{t_{1}}}$ \\
\hline $\begin{array}{c}\text { Competences } \\
\text { Abundance } \\
\qquad\left(\mathbf{C A}_{\mathbf{i}}\right)\end{array}$ & $\begin{array}{l}\text { Definition } \\
\text { The number of distinct ownership relations of a } \\
\text { competence. In terms of social network analysis, it } \\
\text { corresponds to the node's degree. } \\
\text { Potential Use } \\
\text { This indicator measures the level of abundance of a } \\
\text { competence inside the network. A competence with a CA } \\
\text { near to zero means that it is exclusive because it is owned } \\
\text { by few enterprises of the network. }\end{array}$ & $\begin{array}{l}\mathrm{CA}_{\mathrm{i}}=\text { Number of } \\
\text { ownership relations } \\
\text { connected } \\
\text { competence i. }\end{array}$ \\
\hline
\end{tabular}


Table 2. (continued)

\begin{tabular}{|c|c|c|}
\hline $\begin{array}{c}\text { Apparent } \\
\text { Competences } \\
\text { Exclusivity } \\
\text { Index } \\
\left(\mathbf{A C E I}_{\mathbf{i}}\right)\end{array}$ & $\begin{array}{l}\text { Definition } \\
\text { The ratio between the level of proliferation of a } \\
\text { competence and the number of enterprises involved in the } \\
\text { network. } \\
\text { Potential Use } \\
\text { This index gives a simple to compute measure of } \\
\text { exclusivity of a competence. A competence with an ACEI } \\
\text { near to zero means that such competence belongs to few } \\
\text { enterprises. On the other hand, a competence with an } \\
\text { ACEI close to one means that such competence is owned } \\
\text { by all enterprises in the network. }\end{array}$ & $\begin{array}{l}\quad A C E I_{i}=\frac{C A_{i}}{N} \\
\mathrm{~N}-\text {-Number of } \\
\text { enterprises involved } \\
\text { in the network }\end{array}$ \\
\hline $\begin{array}{c}\text { Competences } \\
\text { Exclusivity } \\
\text { Index } \\
\left.(\mathbf{C E I})_{i}\right)\end{array}$ & $\begin{array}{l}\text { Definition } \\
\text { The ratio between the level of proliferation of a } \\
\text { competence and the sum of the number of distinct } \\
\text { competences held by all enterprises involved in the } \\
\text { network. } \\
\text { Potential Use } \\
\text { - Normalization of the level of exclusivity of a } \\
\text { competence in the network. } \\
\text { - Benchmarking with other networks. }\end{array}$ & $\begin{array}{l}C E I_{i}=\frac{C A_{i}}{\sum_{j=1}^{M} C A_{j}} \\
\mathrm{M}-\text { Number of assets } \\
\text { held by the network }\end{array}$ \\
\hline $\begin{array}{c}\text { Competences } \\
\text { Exclusivity } \\
\text { Progress Ratio } \\
\left(\mathbf{C E P R}_{\mathbf{i}}\right)\end{array}$ & $\begin{array}{l}\text { Definition } \\
\text { This index measures the ratio of the exclusivity index of a } \\
\text { competence in two distinct periods of time. } \\
\text { Potential Use } \\
\text { - The aim of this ratio is to measure the variation } \\
\text { of exclusivity of a competence over a period of time. } \\
\text { If: } \\
\qquad E P R_{i\left[t_{1}, t_{2}\right]} \begin{cases}=1 & \text { there is no change } \\
>1 & C E P R_{i} \text { increased } \\
<1 & C E P R_{i} \text { decreased }\end{cases} \\
\text { - Benchmarking with other networks }\end{array}$ & $C E P R_{i\left[t_{1}, t_{2}\right]}=\frac{\left(C E I_{i}\right)_{t_{2}}}{\left(C E I_{i}\right)_{t_{1}}}$ \\
\hline
\end{tabular}

\section{Application of the Proposed Indicators - Brisa Case Study}

\section{Methodology}

The research is based on one case study pointed to the largest Portuguese motorway ${ }^{2}$ is based on two main projects developed by Brisa, namely E_TOLL - Electronic Tolling System, a self-service toll lane where it is possible to pay by bank card or cash, and ALPR - Advanced License Plat Recognition, an enforcement system based on the automatic license plate recognition for situations where the vehicle is not equipped with an on-board-unit (OBU) or the OBU fails to electronically identify the vehicle. Brisa identified E_TOLL and ALPR as the projects that contribute the most to the return on investments. It means that they were relevant in terms of innovation and created value to the company. These were the criteria for choosing E_TOLL and ALPR as pilot projects. On a first stage, companies and other institutions (technology centres, universities) involved in the projects were contacted and invited to cooperate with our research. Empirical data stems from two main sources: in-depth interviews (the basic tool for 
qualitative research on social systems) conducted with key participants belonging to the network, and a brief survey (for quantitative data) applied to participants by using a social network analysis. The involvement of various partners in the network is critical in order to foster a spirit of openness and cooperation in this fundamental process.

\section{Brisa Case Study}

The Brisa company currently operates, on a concession basis, a network of eleven motorways, with a total length of around $1096 \mathrm{~km}$, constituting the main Portuguese road links. Given its importance and dimension, Brisa owns several companies specialising in motoring services aimed at improving the quality of the service provided to customers and increasing its own operating efficiency. The Brisa co-innovation network is a longterm collaborative network (a VBE) that has more than 30 members from several domains and business activities (e.g. research institutions, universities, associations, governmental entities, start-ups, business angels, and suppliers).

\section{The BRISA Network Case Study}

The paper's empirical section is based on one case study pointed to the largest Portuguese motorway operator. Brisa - Auto-estradas de Portugal, founded in 1972, currently operates, on a concession basis, a network of 11 motorways, with a total length of around $1096 \mathrm{~km}$, constituting the main Portuguese road links. The Brisa co-innovation network is a long.term collaborative network (a VBE) that has more than 30 members from several domains and business activities (e.g. researches institutions, universities, associations, governmental entities, start-ups, business angels, and suppliers).

The empirical work is grounded on two main projects developed by BRISA, namely E_TOLL - Electronic Tolling System a self-service toll lane where it is possible to pay by a bank card, money and ALPR - Advanced License Plat Recognition an enforcement system based on the automatic license plate recognition for situation where the vehicle is not equipped with an on-board-unit (OBU) or the OBU fails to electronically identify the vehicle. In the case study three techniques were combined to carry out the empirical research: in-locu observation of the work processes, semi-directive interviews and questionnaires addressed to actors belonging to different organizations that take part of E_TOLL and ALPR.

Taking into account the data collected, Table 3A shows the types of competences used by each partner in the collaborative projects, and Table 3B identifies the types of competences held by each partner in the end of the collaborative projects. Based on the data presented in Table $3 \mathrm{~A}$, and Table 3B, and applying the equations defined in Table 2, Table 4A evaluates the production of new knowledge based on the number of distinct competences held by network in the end of the project E_TOLL and ALPR, and the number of different competences used by the network when the projects started. Based on these data, it is possible to verify that 6 new competences were produced (C19, C20, C21, C22, C23, and C24). Table 4B shows indicators to analyse, for instance, how the competences are held by network members, and the benefits of the entities' participation in a collaborative process.

Assuming that the benefits of an entity can be viewed as the capacity of involvement in a collaborative process; in this case, we are not particularly concerned with whether this benefit is due to the development of exclusive competences, but rather in analysing how many distinct competences might be performed by a member. According to Owned Competences Progress Ratio (OCPRI), at the end of those two projects, there are three 
members, O1, E2, and E4 that had a significant increase in terms of acquiring new competences that might be used in the future, and consequently, they have more

Table 3. A) Record of the competences used by each partner in the collaborative projects. B) Competences held by each partner in the end of the collaborative projects.

\begin{tabular}{|c|c|c|c|c|c|c|c|c|c|c|c|c|c|c|c|c|c|c|c|c|c|c|c|c|c|}
\hline & \multicolumn{24}{|c|}{ Competences } & \multirow[b]{2}{*}{ Total } \\
\hline Entity & C1 & C2 & $\mathrm{C3}$ & C4 & C5 & C6 & C7 & C8 & C9 & C10 & C11 & C12 & C13 & C14 & C15 & C16 & C17 & C18 & C19 & C2O & C21 & C22 & C23 & C24 & \\
\hline 01 & 1 & 1 & 1 & 1 & 0 & 0 & 0 & 0 & 0 & 0 & 0 & 0 & 0 & 0 & 0 & 0 & 0 & 0 & 0 & 0 & 0 & 0 & 0 & 0 & 4 \\
\hline E1 & 0 & 1 & 0 & 1 & 0 & 0 & 0 & 0 & 0 & 0 & 0 & 0 & 0 & 0 & 0 & 0 & 0 & 0 & 0 & 0 & 0 & 0 & 0 & 0 & 2 \\
\hline E2 & 0 & 0 & 0 & 0 & 0 & 0 & 0 & 0 & 0 & 0 & 0 & 0 & 0 & 0 & 0 & 0 & 0 & 1 & 0 & 0 & 0 & 0 & 0 & 0 & 1 \\
\hline E3 & 0 & 0 & 0 & 0 & 1 & 0 & 0 & 0 & 0 & 0 & 0 & 0 & 0 & 0 & 0 & 0 & 0 & 0 & 0 & 0 & 0 & 0 & 0 & 0 & 1 \\
\hline E4 & 0 & 1 & 0 & 1 & 0 & 1 & 0 & 0 & 0 & 0 & 0 & 0 & 0 & 0 & 0 & 0 & 0 & 0 & 0 & 0 & 0 & 0 & 0 & 0 & 3 \\
\hline E5 & 0 & 0 & 0 & 0 & 0 & 0 & 1 & 0 & 0 & 0 & 0 & 0 & 0 & 0 & 0 & 0 & 0 & 0 & 0 & 0 & 0 & 0 & 0 & 0 & 1 \\
\hline E6 & 0 & 0 & 0 & 0 & 0 & 0 & 0 & 0 & 0 & 0 & 0 & 1 & 1 & 1 & 1 & 1 & 0 & 0 & 0 & 0 & 0 & 0 & 0 & 0 & 5 \\
\hline E7 & 1 & 0 & 0 & 0 & 0 & 0 & 0 & 0 & 0 & 0 & 0 & 0 & 0 & 0 & 1 & 0 & 1 & 0 & 0 & 0 & 0 & 0 & 0 & 0 & 3 \\
\hline 02 & 0 & 0 & 0 & 0 & 0 & 0 & 0 & 1 & 1 & 1 & 1 & 0 & 0 & 0 & 0 & 0 & 0 & 0 & 0 & 0 & 0 & 0 & 0 & 0 & 4 \\
\hline Total & 2 & 3 & 1 & 3 & 1 & 1 & 1 & 1 & 1 & 1 & 1 & 1 & 1 & 1 & 2 & 1 & 1 & 1 & 0 & 0 & 0 & 0 & 0 & 0 & 18 \\
\hline $\mathbf{B}$ & \multicolumn{24}{|c|}{ Competences } & \\
\hline Entity & C1 & $\mathrm{C} 2$ & C3 & C4 & C5 & C6 & C7 & $\mathrm{C} 8$ & C9 & C10 & C11 & C12 & C13 & C14 & C15 & C16 & C17 & C18 & C19 & C20 & C21 & C22 & C23 & C24 & Total \\
\hline 01 & 1 & 1 & 1 & 1 & 0 & 0 & 0 & 0 & 0 & 0 & 0 & 0 & 0 & 0 & 0 & 0 & 0 & 0 & 1 & 1 & 1 & 1 & 1 & 0 & 9 \\
\hline E1 & 0 & 1 & 0 & 1 & 0 & 0 & 0 & 0 & 0 & 0 & 0 & 0 & 0 & 0 & 0 & 0 & 0 & 0 & 0 & 0 & 0 & 0 & 0 & 0 & 2 \\
\hline E2 & 0 & 0 & 1 & 1 & 0 & 0 & 0 & 0 & 0 & 0 & 0 & 0 & 0 & 0 & 0 & 0 & 0 & 1 & 0 & 0 & 0 & 0 & 0 & 0 & 3 \\
\hline E3 & 0 & 0 & 0 & 0 & 1 & 0 & 0 & 0 & 0 & 0 & 0 & 0 & 0 & 0 & 0 & 0 & 0 & 0 & 0 & 0 & 0 & 0 & 0 & 0 & 1 \\
\hline E4 & 1 & 1 & 1 & 1 & 0 & 1 & 0 & 0 & 0 & 0 & 0 & 0 & 0 & 0 & 0 & 0 & 0 & 0 & 0 & 0 & 0 & 0 & 0 & 0 & 5 \\
\hline E5 & 0 & 0 & 0 & 0 & 0 & 0 & 1 & 0 & 0 & 0 & 0 & 0 & 0 & 0 & 0 & 0 & 0 & 0 & 0 & 0 & 0 & 0 & 0 & 0 & 1 \\
\hline E6 & 0 & 0 & 0 & 0 & 0 & 0 & 0 & 0 & 0 & 0 & 0 & 1 & 1 & 1 & 1 & 1 & 0 & 0 & 0 & 0 & 0 & 0 & 0 & 0 & 5 \\
\hline E7 & 1 & 0 & 0 & 0 & 0 & 0 & 0 & 0 & 0 & 0 & 0 & 0 & 0 & 0 & 1 & 0 & 1 & 0 & 0 & 0 & 0 & 0 & 0 & 0 & 3 \\
\hline 02 & 0 & 0 & 0 & 0 & 0 & 0 & 0 & 1 & 1 & 1 & 1 & 0 & 0 & 0 & 0 & 0 & 0 & 0 & 0 & 0 & 0 & 0 & 0 & 1 & 5 \\
\hline Total & 3 & 3 & 3 & 4 & 1 & 1 & 1 & 1 & 1 & 1 & 1 & 1 & 1 & 1 & 2 & 1 & 1 & 1 & 1 & 1 & 1 & 1 & 1 & 1 & 34 \\
\hline
\end{tabular}

Table 4. Indicators for Knowledge production and circulation analysis

\begin{tabular}{|c|c|c|c|c|c|c|c|c|c|c|c|c|c|c|c|c|}
\hline & & \multirow{2}{*}{\multicolumn{2}{|c|}{ A }} & \multirow{2}{*}{\multicolumn{2}{|c|}{ Start }} & & \multirow[t]{2}{*}{$\mathbf{C}$} & \multirow[b]{2}{*}{ Competences } & \multicolumn{3}{|c|}{ Start } & \multicolumn{3}{|c|}{ Finish } & \multirow[b]{2}{*}{ CEPR } \\
\hline & & & & & & Finish & & & & CA & ACEI & CEI & CA & ACEI & CEI & \\
\hline & & \multirow{2}{*}{\multicolumn{2}{|c|}{$\mathbf{C}$}} & \multirow{2}{*}{\multicolumn{2}{|c|}{18}} & \multirow{2}{*}{\multicolumn{2}{|c|}{24}} & C1 & Computer vision & 2 & 0,22 & 0,11 & 3 & 0,33 & 0,09 & 0,79 \\
\hline & & & & & & & & C2 & Software Engineering & 3 & 0,33 & 0,17 & 3 & 0,33 & 0,09 & 0,53 \\
\hline & & & & & & & & C3 & Infrared illumination & 1 & 0,11 & 0,06 & 3 & 0,33 & 0,09 & 1,59 \\
\hline \multirow[t]{2}{*}{ B } & \multirow{2}{*}{\multicolumn{3}{|c|}{ Start }} & \multirow{2}{*}{\multicolumn{3}{|c|}{ Finish }} & & C4 & Automatic pattern recognition & 3 & 0,33 & 0,17 & 4 & 0,44 & 0,12 & 0,71 \\
\hline & & & & & & & \multirow[b]{2}{*}{ OCPR } & C5 & Toll systems & 1 & 0,11 & 0,06 & 1 & 0,11 & 0,03 & 0,53 \\
\hline Entity & TOC & $\mathrm{AOCl}$ & oCl & TOC & AOCI & oCI & & C6 & Information Systems Architecture, & 1 & 0,11 & 0,06 & 1 & 0,11 & 0,03 & 0,53 \\
\hline 01 & 4 & 0,22 & 0,17 & 9 & 0,38 & 0,27 & 1,64 & C7 & Industrial Design & 1 & 0,11 & 0,06 & 1 & 0,11 & 0,03 & 0,53 \\
\hline E1 & 2 & 0,11 & 0,08 & 2 & 0,08 & 0,06 & 0,73 & C8 & Modelling of products & 1 & 0,11 & 0,06 & 1 & 0,11 & 0,03 & 0,53 \\
\hline $\begin{array}{l}\text { E2 } \\
\text { E3 }\end{array}$ & $\frac{1}{1}$ & $\begin{array}{l}0,06 \\
0,06\end{array}$ & $\begin{array}{l}0,04 \\
0,04\end{array}$ & $\begin{array}{l}3 \\
1\end{array}$ & $\begin{array}{l}0,13 \\
0,04\end{array}$ & $\begin{array}{l}0,09 \\
0,03\end{array}$ & $\begin{array}{l}2,18 \\
0,73\end{array}$ & C9 & Rapid prototyping & 1 & 0,11 & 0,06 & 1 & 0,11 & 0,03 & 0,53 \\
\hline E4 & 3 & 0,00 & 0,13 & $\frac{1}{5}$ & 0,04 & 0,15 & $\begin{array}{l}1,21 \\
1,21\end{array}$ & C10 & Development of molds & 1 & 0,11 & 0,06 & 1 & 0,11 & 0,03 & 0,53 \\
\hline E5 & 1 & 0,06 & 0,04 & 1 & 0,04 & 0,03 & 0,73 & C11 & Plastic injection & 1 & 0,11 & 0,06 & 1 & 0,11 & 0,03 & 0,53 \\
\hline E6 & 5 & 0,28 & 0,21 & 5 & 0,21 & 0,15 & 0,73 & C12 & Functional Tests & 1 & 0,11 & 0,06 & 1 & 0,11 & 0,03 & 0,53 \\
\hline E7 & 3 & 0,17 & 0,13 & 3 & 0,13 & 0,09 & 0,73 & C13 & Software Development & 1 & 0,11 & 0,06 & 1 & 0,11 & 0,03 & 0,53 \\
\hline \multirow[t]{11}{*}{02} & 4 & 0,22 & 0,17 & 5 & 0,21 & 0,15 & 0,91 & C14 & Software Architecture & 1 & 0,11 & 0,06 & 1 & 0,11 & 0,03 & 0,53 \\
\hline & & & & & & & & C15 & Project Management & 2 & 0,22 & 0,11 & 2 & 0,22 & 0,06 & 0,53 \\
\hline & & & & & & & & C16 & Functional Analysis & 1 & 0,11 & 0,06 & 1 & 0,11 & 0,03 & 0,53 \\
\hline & & & & & & & & C17 & Remote monitoring & 1 & 0,11 & 0,06 & 1 & 0,11 & 0,03 & 0,53 \\
\hline & & & & & & & & C18 & Supplier of equipment for image capture & 1 & 0,11 & 0,06 & 1 & 0,11 & 0,03 & 0,53 \\
\hline & & & & & & & & C19 & Electronic Toll Collection (ETC) systems & 0 & 0,00 & 0,00 & 1 & 0,11 & 0,03 & $\cdots$ \\
\hline & & & & & & & & $\mathrm{C} 20$ & Information Systems open to multi-vendor & 0 & 0,00 & 0,00 & 1 & 0,11 & 0,03 & $-\cdots$ \\
\hline & & & & & & & & c21 & Automatic vehicle identification systems & 0 & 0,00 & 0,00 & 1 & 0,11 & 0,03 & --- \\
\hline & & & & & & & & C22 & Communication systems between vehicles & 0 & 0,00 & 0,00 & 1 & 0,11 & 0,03 & $-\cdots$ \\
\hline & & & & & & & & $\mathrm{C} 23$ & Classification systems of vehicles & 0 & 0,00 & 0,00 & 1 & 0,11 & 0,03 & $\cdots$ \\
\hline & & & & & & & & C24 & Short run production & 0 & 0,00 & 0,00 & 1 & 0,11 & 0,03 & --- \\
\hline
\end{tabular}


opportunities to participate in collaborative processes than those who have a low ratio. Table 4C illustrates some examples of indicators to evaluate, for instance, the level of exclusivity of each competence and the circulation of competences among members. Based on these data, it is possible to verify, for example, that according to Competences Exclusivity Progress Ratio (CEPR), the highest value belongs to competence C3 (infrared illumination) that had a great proliferation among members of the network.

\section{Conclusions}

Reaching a better characterization and understanding of the mechanisms of production and circulation of knowledge in co-innovation networks is an important element for a better understanding of the behavioral aspects, and also to improve the sustainability of this organizational form.

The development of a set of indicators to capture and measure the circulation and production of knowledge can be a useful instrument to the manager of this network, as a way to support the promotion of collaborative behaviors, and for a member as a way to extract the advantages of belonging to a network. Using simple calculations as illustrated above, it is possible to extract some indicators. Some preliminary steps in this direction were presented. However, the development of indicators to measure the potential impacts and worth related to production and circulation of knowledge, for instance, at a member level, in terms of capacity of generating new ideas, development of new processes, new products or services, organizational improvement through the combination of the existent resources and diversity of cultures and experiences of other enterprises is not yet well understood and requires further research and development.

Acknowledgments. This work was partially supported by BRISA Innovation and Technology (BIT) through a research and development project.

\section{References}

1. Argote, L., et al.: Knowledge Transfer in Organizations: Learning from the Experience of Others. Organizational Behavior and Human Decision Processes 82(1), 1-8 (2000)

2. Camarinha-Matos, L.M., Abreu, A.: A contribution to understand collaboration benefits. In: Camarinha-Matos, L.M. (ed.) Emerging Solutions for Future Manufacturing Systems. IFIP, vol. 159, Springer, Boston (2004)

3. Abreu, A., Camarinha-Matos, L.M.: Understanding Social Capital in Collaborative Networks. In: Ortiz, Á., Franco, R.D., Gasquet, P.G. (eds.) BASYS 2010. IFIP AICT, vol. 322, pp. 109-118. Springer, Heidelberg (2010)

4. Murteira, M.: Economia do conhecimento. Quimera Editores, Lisboa (2004)

5. Grant, R., Spender, J.-C.: Knowledge and the Firm: an overview. Strategic Management Journal 17 (1996)

6. Gibbons, et al.: The New Production of Knowledge: The Dynamics of Science and Research in Contemporary Societies. Sage, London (1994)

7. Urze, P., Abreu, A.: Knowledge transfer assessment in a co-innovation network. In: Camarinha-Matos, L.M., Xu, L., Afsarmanesh, H. (eds.) PRO-VE 2012. IFIP AICT, vol. 380, pp. 605-615. Springer, Heidelberg (2012)

8. Abreu, A., Camarinha-Matos, L.M.: An Approach to Measure Social Capital in Collaborative Networks. In: Camarinha-Matos, L.M., Pereira-Klen, A., Afsarmanesh, H. (eds.) PRO-VE 2011. IFIP AICT, vol. 362, pp. 29-40. Springer, Heidelberg (2011) 